and share their knowledge with adult MCS surgeons, adding an important BVAD option for the adult MCS team.

\footnotetext{
References

1. Bartfay S-E, Dellgren G, Hallhagen S, Wåhlander H, Dahlberg P, Redfors B, et al. Durable circulatory support with a paracorporeal device as an option for pediatric and adult heart failure patients. J Thorac Cardiovasc Surg. 2021;161:1453-64.e4.

2. Morales DLS, Rossano JW, VanderPluym C, Lorts A, Cantor R, St Louis JD, et al; Pedimacs Investigators. Third annual pediatric interagency registry for mechanical circulatory support (pedimacs) report: preimplant characteristics and outcomes. Ann Thorac Surg. 2019;107:993-1004.
}

3. Kirov H, Faerber G, Doenst T. Implantation of a HeartMate 3 left ventricular assist device in a patient with congenitally corrected transposition of the great arteries. $J$ Heart Lung Transplant. 2019;38:S370.

4. Cedars A, Vanderpluym C, Koehl D, Cantor R, Kutty S, Kirklin JK. An interagency registry for mechanically assisted circulatory support (INTERMACS) analysis of hospitalization, functional status, and mortality after mechanical circulatory support in adults with congenital heart disease. J Heart Lung Transplant. 2018;37:619-30.

5. Kirklin JK, Xie R, Cowger J, de By TMMH, Nakatani T, Schueler S, et al. Second annual report from the ISHLT mechanically assisted circulatory support registry. $J$ Heart Lung Transplant. 2018;37:685-91

6. Arabía FA, Cantor RS, Koehl DA, Kasirajan V, Gregoric I, Moriguchi JD, et al. Interagency registry for mechanically assisted circulatory support report on the total artificial heart. J Heart Lung Transplant. 2018;37:1304-12.
See Article page 1453.

\section{Commentary: Rejuvenation of a trusted tool}

\author{
Chet R. Villa, MD, and David L. S. Morales, MD
}

Axial and centrifugal continuous-flow (cf) ventricular assist devices (VADs) rapidly supplanted pulsatile VADs as the devices of choice for adults in the mid-to-late 2000s. Although the field has largely consolidated toward the use of cfVADs in large patients requiring left ventricular support alone, the anatomic challenges of cfVAD implantation in children (generally $<20 \mathrm{~kg}$ ), certain adults with congenital heart disease, and patients requiring biventricular support require a more individualized approach.

In the current issue of the Journal, Bartfay and colleagues ${ }^{1}$ describe the use of the EXCOR (Berlin Heart, Inc, The Woodlands, Tex) in these populations. The overall outcomes are good and underscore the fact that the EXCOR performs quite well in appropriately selected

\footnotetext{
From the Heart Institute, Cincinnati Children's Hospital Medical Center, Cincinnati, Ohio.

Disclosures: Dr Morales is a consultant for Berlin Heart, Medtronic, Abbott, and SynCardia. Dr Villa reported no conflicts of interest.

The Journal policy requires editors and reviewers to disclose conflicts of interest and to decline handling or reviewing manuscripts for which they may have a conflict of interest. The editors and reviewers of this article have no conflicts of interest.

Received for publication May 7, 2020; revisions received May 7, 2020; accepted for publication May 11, 2020; available ahead of print May 25, 2020.

Address for reprints: David L. S. Morales, MD, The Heart Institute at Cincinnati Children's Hospital Medical Center, 3333 Burnet Ave, MLC 2004, Cincinnati, OH 45229 (E-mail: David.Morales@cchmc.org).

J Thorac Cardiovasc Surg 2021;161:1466-7

$0022-5223 / \$ 36.00$

Copyright (C) 2020 by The American Association for Thoracic Surgery

http://dx.doi.org/10.1016/j.jtcvs.2020.05.039
}

Check for updates

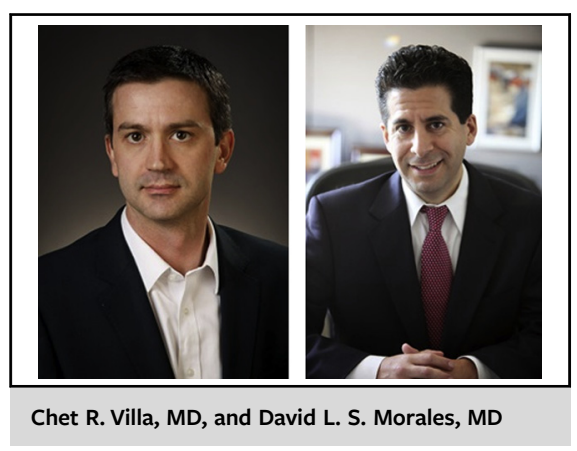

CENTRAL MESSAGE

Patient selection remains fundamental to outcomes even as the VAD armamentarium expands and evolves.

patients. These data are especially notable when considering the current study also depicts feasibility and utility of discharge on the EXCOR with the mobile driving unit. The study is consistent with overall outcomes within the field showing improved outcomes in the current era as patient selection and anticoagulation evolve and centers garner more experience. ${ }^{2,3}$ However, a more in-depth examination of the use of the device by the authors in a biventricular assist device (BiVAD) configuration is warranted. The current results are notably better than the larger experience within the field, where BiVAD support has a 6 -month survival of $\sim 65 \% .{ }^{4}$ This difference in outcome is likely a function of patient characteristics as well as a very liberal approach to the use of BiVAD support based on preoperative right ventricular function. 
However, many would argue that most of these patients did not need a BiVAD. The authors fall into the common misconception that the use of a BiVAD is equal to the need of a BiVAD.

While late implantation of right ventricular support after left VAD is clearly a risk factor for poor outcomes, ${ }^{5}$ "prophylactic" use of BiVAD therapy has not been shown to improve outcomes after controlling for preoperative patient characteristics. ${ }^{6}$ These data, in conjunction with the broader outcomes in patients implanted with a left cfVAD, suggest the focus should be on earlier implantation rather broader use of BiVAD therapy. ${ }^{7}$ There is morbidity and mortality associated with the use of BiVAD therapy when left VAD alone will suffice in $90 \%$ to $95 \%$ of patients. Bartfay and colleagues have described the potential utility of the EXCOR in the current era; however, outcomes can only be optimized when the right device is implanted in the right patient at the right time, which regularly results in no right VAD.

\section{References}

1. Bartfay S, Dellgren G, Hallhagen S, Wåhlander H, Dahlberg P, Redfors B, et al Durable circulatory support with a paracorporeal device as an option for pediatric and adult heart failure patients. J Thorac Cardiovasc Surg. 2021;161: 1453-64.e4

2. Miera O, Morales DLS, Thul J, Amodeo A, Menon AK, Humpl T. Improvement of survival in low-weight children on the Berlin Heart EXCOR ventricular assist device support. Eur J Cardiothorac Surg. 2019;55:913-9.

3. VanderPluym CJ, Cantor RS, Machado D, Boyle G, May L, Griffiths E, et al Utilization and outcomes of children treated with direct thrombin inhibitors on paracorporeal ventricular assist device support. ASAIO J. November 20, 2019 [Epub ahead of print].

4. Kormos RL, Cowger J, Pagani FD, Teuteberg JJ, Goldstein DJ, Jacobs JP, et al The Society of Thoracic Surgeons intermacs database annual report: evolving indications, outcomes, and scientific partnerships. Ann Thorac Surg. 2019;107: 341-53

5. Takeda K, Naka Y, Yang JA, Uriel N, Colombo PC, Jorde UP, et al. Outcome of unplanned right ventricular assist device support for severe right heart failure after implantable left ventricular assist device insertion. J Heart Lung Transplant. 2014; 33:141-8.

6. Zafar F, Jefferies JL, Tjossem CJ, Bryant R III, Jaquiss RD, Wearden PD, et al Biventricular Berlin Heart EXCOR pediatric use across the United States. Ann Thorac Surg. 2015;99:1328-34

7. Kanwar MK, Lohmueller LC, Kormos RL, Teuteberg JJ, Rogers JG, Lindenfeld J, et al. A Bayesian model to predict survival after left ventricular assist device implantation. JACC Heart Fail. 2018;6:771-9
See Article page 1453.

\section{Commentary: The pneumatic para-trouper}

\section{Tomasz A. Timek, MD, PhD}

Advanced congestive heart failure has reached epidemic proportions in the United States, with the number of endstage patients exceeding the number of available organs for transplantation by an order of magnitude. ${ }^{1,2}$ Mechanical support devices have been introduced and refined to offer bridging and long-term therapy for the failing left ventricle, with implantable continuous-flow devices now offering

\footnotetext{
From the Division of Cardiothoracic Surgery, Spectrum Health, and Michigan State University College of Human Medicine, Grand Rapids, Mich.

Disclosures: The author reported no conflicts of interest.

The Journal policy requires editors and reviewers to disclose conflicts of interest and to decline handling or reviewing manuscripts for which they may have a conflict of interest. The editors and reviewers of this article have no conflicts of interest.

Received for publication May 31, 2020; revisions received May 31, 2020; accepted for publication June 2, 2020; available ahead of print June 23, 2020.

Address for reprints: Tomasz A. Timek, MD, PhD, Division of Cardiothoracic Surgery, Spectrum Health, Michigan State University College of Human Medicine, 100 Michigan Ave NE, Grand Rapids, MI 49503 (E-mail: tomasz.timek@ spectrumhealth.org).

J Thorac Cardiovasc Surg 2021;161:1467-8 $0022-5223 / \$ 36.00$

Copyright (C) 2020 Published by Elsevier Inc. on behalf of The American Association for Thoracic Surgery

http://dx.doi.org/10.1016/j.jtcvs.2020.06.009
}

Check for updates

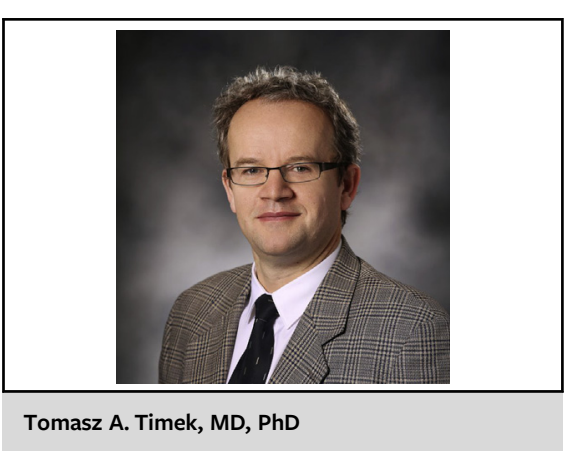

CENTRAL MESSAGE

The EXCOR pneumatic paracorporeal ventricular assist device offers good clinical outcomes as a bridge to transplantation in adult and pediatric patients.

2-year outcomes that rival heart transplantation. ${ }^{3}$ However, pediatric patients and adults with right ventricular failure are often not candidates for this life-saving therapy and require in-hospital extracorporeal support, which is associated with significant morbidity, mortality, and cost. In the current issue of the Journal, Bartfay and colleagues ${ }^{4}$ report their experience with the EXCOR pneumatic paracorporeal 